\title{
NEW PERSPECTIVE ANALYSIS OF MANAGEMENT GOVERNANCE IN FACING THE DIGITAL ERA IN BHAYANGKARA HOSPITAL H.S. SAMSOERI MERTOJOSO SURABAYA
}

\author{
Wijayanti Leevi Tanu*, Musriha, Pudjowati Juliani, Balafif Mamak M. \\ Master's Study Program of Management, University Bhayangkara Surabaya, Indonesia \\ *E-mail: leevitw@gmail.com
}

\begin{abstract}
Clinical governance as system was first developed in the UK in the 90's decade. Some of the challenges that arise in healthcare services are still experiencing in balance between needs and health care providers, especially in small towns and rural areas. Even if we compare between the number of beds available throughout the hospital and the growing community needs, Indonesia is in the order of a country with a low ratio $(0.8$ per 1000$)$ compared to other ASEAN countries. Many hospital managers are more focused on expansion of facilities and still look at the eye towards digital transformation due to their high bargaining position due to lack of competition. In addition to this, more and more hospitals in Indonesia have implemented the system of IT Hospital Information System including centralization of medical records database. However, due to lack of standardization documentation and business process, implementation of this IT system works independently and less integrated with other systems Bhayangkara Hospital H.S.Samsoeri Mertojoso Surabaya as one of the health facilities that provide health services has a very important role in improving public health, implementing health services and has a means of infrastructure and advanced quality, Professional and immoral. Bhayangkara Hospital H.S. Samsoeri Mertojoso Surabaya organizes police medical services and procedura I police health in the increase of the quality and safety of patients for police, civil servant police, his family and the general public.
\end{abstract}

\section{KEY WORDS}

Analysis, governance management, hospitals.

As for what will be discussed in this study to determine the role of clinical management in the Bhayangkara H.S.Samsoeri Mertojoso Hospital Surabaya, as a type B hospital in eastern Indonesia. As well as knowing the implementation of Good Clinical Governance at Bhayangkara H.S Samsoeri Mertojoso Hospital Surabaya. The concept of the components of clinical governance activities that you want to know includes:

1. Focus on customer (customer value), is consumer value, which encourages health services to involve consumers and stakeholders in maintaining and improving service performance and in planning for the future of the organization. Consumers in this case are not only patients, but also include local government and non-government organizations. Examples of values held by consumers, for example, patients believe that a good hospital is a hospital where the doctor is able to explain well about the disease experienced by the patient and also the doctor can explain the medical action plan to be carried out. Effective consumer engagement requires good leadership to ensure that it is beneficial, effective and provides positive outcomes for health services. The expected outcome is:

- Increased employee understanding of health services and more responsive to customer / patient needs.

- Increasing customer / patient knowledge and also increasing customer / patient participation in health services and management.

- Increase customer / patient confidence in health service organizations / hospitals.

- Improved customer / patient outcomes. By implementing Clinical Governance, it is hoped that the hospital can pay more attention to consumers by paying attention to the values held by these consumers. 
2. Clinical performance and evaluation, which aims to ensure the use and monitoring and evaluation of evidence-based clinical standards. The result is a culture, where organizational evaluation and clinical performance, including clinical audits, are common and expected in every clinical service organization. There are three tools that can be used to help health care organizations achieve these results, namely clinical standards, indicators. clinics, and clinical audits. This has been realized by the hospital by having a list of clinical indicators that are used to measure clinical performance. The stage that still needs to be done by the hospital is to evaluate the results of the clinical performance measurement. There needs to be cooperation from all parties in the hospital, including the medical, nursing, and marketing committees. If the clinical performance measurement shows good results, then this can be used as a tool for hospital marketing, namely by showing the community that the hospital is able to provide good clinical services as shown by evidence of clinical performance measurement. The expected outcome is:

- Development of clinical pathways in clinical practice. Clinical path way is an integrated planning concept that summarizes every step taken to a patient, from the time the patient enters to leaving the hospital based on medical service standards, nursing care standards, and other evidence-based health worker service standards with results that can be measured in a period of time. During the hospital (Hunter, 2017). Clinical path way is a schedule of medical and nursing procedures, including diagnostic tests, treatment and consultation designed for efficiency and coordination of the hospital clinical management program (Blesser, et al., 2014).

- Increased adherence to evidence-based clinical practice and reduced variation in clinical practice.

- Improved customer / patient outcomes.

- Reduced health care costs through reduced side effects.

3. Staff development and training all hospital staff, including managers and clinical staff, receive sufficient information, references, training and professional development to support clinical governance activities. The hospital must be able to show that: - If all staff needs information, they can easily get enough information, references, training and professional development to support activities in Clinical Governance (Kasyifi, 2014). Records of training are kept, monitored and reviewed. All new staff is given an introduction (orientation) program on policies and strategies in Clinical Governance.

In this digital era, the hospital cannot be separated from information technology governance in building and facilitating the performance of a company. Information Technology Governance or IT Governance as the implementation of Information Technology performance so that it can be directed and in accordance with company goals (Supriyatno et al, 2015). In addition to Information Technology Governance, Information Technology services are the most important elements that must be considered for companies. Service is also a driving factor for the company's success. As one important thing, every company will try its best to provide the best service for its customers. What's more, in the era of the development of Information Technology, of course companies try to attract the sympathy of customers by using technology services, which of course will make it easier for customers and improve the quality of the company in the eyes of their customers. Likewise with the Hospital of Bhayangkara H. S. Samsoeri Mertojoso Surabaya who want to provide optimal service.

The government does not remain silent in facing current developments. Various regulations have been issued to ensure a balance between the needs of the community and industry players, so that no one is disadvantaged. In the health / hospital industry, digitalization is driven by an increase in good service levels, especially the speed and accuracy of services for patients. Currently the hospital has started using electronic medical records (Electronic Medical Record) in storing patient historical data. Medical records are written or recorded information about identity, history, physical determination, laboratory, diagnosis of all medical services and actions given to patients and treatment, whether 
hospitalized, outpatient or emergency services. Medical records have a very broad meaning, not just recording activities, but have the meaning as a medical record management system, namely starting recording as long as patients receive medical services, followed by handling medical record files which include organizing storage and releasing files from storage areas for serve requests / borrowings if from patients or for other purposes. Imagine if this has been implemented thoroughly, patient data can be used throughout the hospital easily without being limited to locations, so that the speed and accuracy of services can be better provided. If we look at the financial industry sector, it is not uncommon if all information is currently digital and used in various forms.

Challenges to digital transformation systems in health care often come from nontechnical aspects. According to Harold F. Wolf, president and CEO of the Healthcare Information and Management Systems Society (HIMSS), changing work culture is often an obstacle to developing the system. There are many challenges in terms of mindset or mindset, organizational structure, and organizational governance. We all have experienced difficulties when using doctors and hospitals. Starting from the complicated registration process, bookings must use the telephone, long and uncertain waiting times, manual and complicated payment processes, especially when using insurance. And that's just the tip of the iceberg of health care problems in Indonesia. At Bhayangkara H.S.Samsoeri Mertojoso Hospital, Surabaya, for patient registration services to outpatient clinics, they have used online registration through the Playstore application and can also use services via WhatsApp.

Some of the challenges that arise in health services include the imbalance between needs and health service providers, especially in small cities and rural areas. Even when compared between the number of beds available in all hospitals and the increasing needs of the community, Indonesia is in the list of countries with a low ratio (0.8 per 1000) compared to other ASEAN countries. Pridmore (2007) many hospital managers are more focused on facility expansion and still underestimate digital transformation because of the high bargaining position due to lack of competition. Besides that, currently there are more and more hospitals in Indonesia that have implemented the IT Hospital Information System, including the centralization of the medical records database. However, due to the lack of standardization of documentation and business processes, the implementation of this IT system works independently and is less integrated with other systems. Many hospitals are already dependent on outdated technology, making it difficult to update to meet the expectations of patients who want to access information quickly via mobile. Syahril (2015) Especially when the IT system in the hospital is built by various different vendors so that it does not have a continuity of the technology roadmap so that it can continue to be developed in the future. Then as in other industries, the biggest challenge of digital transformation is the organizational culture and bureaucracy that hinders changes to better governance. One of the biggest difficulties is the education and implementation process which requires commitment from the top level to the staff. This requires an appropriate change management strategy and is regularly evaluated. Doctors as the most important stakeholder in the hospital digital ecosystem are sometimes less receptive to these changes.

Bhayangkara HS Samsoeri Mertojoso Hospital Surabaya, which is a type B hospital and fully accredited, is expected to be able to provide quality health services, in accordance with applicable rules. Police medical technical and police health, for the implementation of operational and administrative techniques responsible to the Head of Regional Units and the Head of the corresponding organizational unit, Bhayangkara HS Samsoeri Mertojoso Hospital Surabaya as one of the health facilities that provide health services has a very important role in improving public health, carry out comprehensive health services and have advanced and sophisticated facilities as well as qualified, professional and moral human resources. Bhayangkara H. S. Samsoeri Hospital. Mertojoso Surabaya organizes Police Medical and Police Health Services in a procedural manner in improving the quality and patient safety for members of the Police, PNS Polri, their families and the general public.

Based on this background, the problem formulations in this study were identified as follows: 
- How to apply a new perspective of management governance at Bhayangkara H. S. Samsoeri Mertojoso Surabaya for now in facing the digital era?

- How to make recommendations that can be made at Bhayangkara H. S. Samsoeri Mertojoso Hospital Surabaya so that they are in accordance with the principles of management governance that are expected in the face of the digital era?

\section{LITERATURE REVIEW}

As developed by the Department of Health, the Western Australian Department of Health defines it as a systematic and integrated approach to assuring and assessing clinical responsibility and accountability through quality and safety improvements that lead to optimal clinical outcomes.

Presidential Decree 77 of 2015, concerning Hospital Organization Guidelines regulates hospital governance Setting hospital organizational guidelines aims to create an effective, efficient and accountable hospital organization in achieving the hospital's vision and mission in accordance with good corporate governance (Good Corporate Governance). ) and good clinical governance (Good Clinical Governance). Djasry (2006), Good Clinical Governance is again hotly discussed in Indonesia in the era of National Health Insurance, where health service facilities are required to be able to provide quality health services but still be able to keep service costs efficient (quality control and cost control) in accordance with Article 1 Number 3 of Law No.4 of 2009. Since 2006, in Indonesia, clinical management has been implemented in various government and private hospitals (RS) as well as in various Puskesmas. Although the details of the application of clinical management at the first level health care and secondary-tertiary level are different, in general the basic concept remains the same. The basic concept that needs to be understood before starting to implement various activities related to good clinical governance is an understanding of the pillars / components that build clinical governance and the standards that can be used to assess / audit the appropriateness of the application of good clinical governance. In the following, the authors will describe the 4 pillars and 8 clinical governance standards as well as how to carry out audits / assessments with sample applications in hospitals but can also apply to first-level health service facilities.

The pillars of Good Clinical Governance have many concepts about components of clinical governance activities. However, in general, they consist of four pillars as developed in the state:

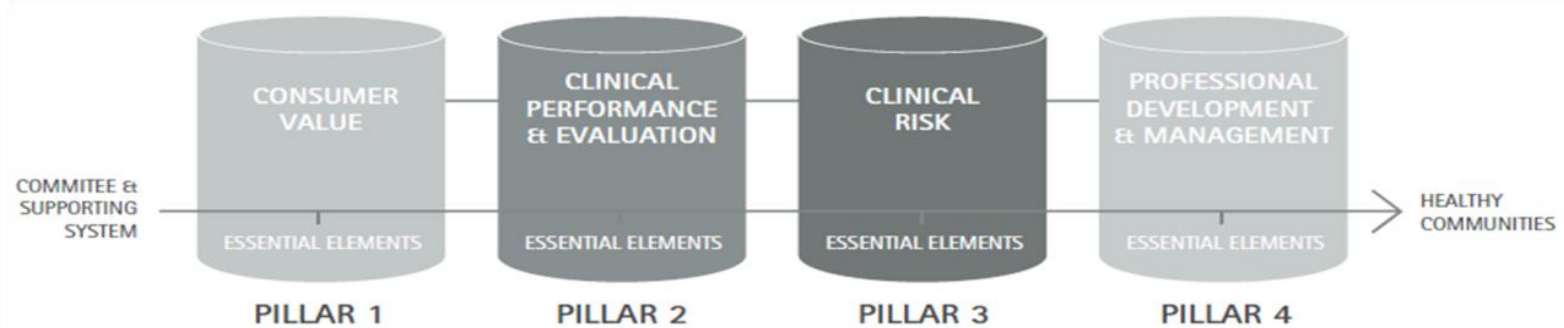

GUIDING PRINCIPLES - PATIENT OUTCOME BASED - CLINICAL LEADERSHIP \& INVOLVEMENT - INFORMATION AND DATA BASED SELF SUSTAINING - SYSTEM-WIDE APPROACH - LEARNING CULTURE - PARTNERSHIPS

Figure 1 - Clinical Governance for the Western Australian Public Health System

1. Focus on customer (customer value) the first pillar is consumer value, which encourages health services to involve consumers and stakeholders in maintaining and improving service performance and in planning for the future of the organization. Consumers in this case are not only patients, but also include local government and non-government organizations. In implementing this first pillar, apart from involving consumers, the hospital must also pay attention to the values held by these consumers. Examples of values held by consumers, for example, patients believe that a good hospital is a hospital where the doctor is able to explain well about the 
disease experienced by the patient and also the doctor can explain the medical action plan to be carried out. Effective consumer engagement requires good leadership to ensure that it is beneficial, effective and provides positive outcomes for health services. Here are the essentials of customer value:

- Sustainable relationship, which involves consumers who emphasize two-way communication between consumers and hospitals. Examples include informed consent, complaint management, patient satisfaction surveys and providing information about services for patients and their families (Widayat, 2009).

- Consumer participation, which involves consumers in hospital planning, development policies and decision making. This is done to ensure to consumers that the hospital really provides services that are easily accessible, fair and responsive to local priorities. The expected outcomes are: 1 . Increased employee understanding of health services and more responsive to customer / patient needs, 2. Customer / patient knowledge enhancement and also increased customer / patient participation in health services and management, 3. Increased customer / patient trust in health service organization / hospital, 4. Improved customer / patient outcomes. By implementing Clinical Governance, it is hoped that the hospital can pay more attention to consumers by paying attention to the values held by these consumers.

2. Clinical performance and evaluation This second pillar aims to ensure the use and monitoring and evaluation of evidence-based clinical standards. The result is a culture, where organizational evaluation and clinical performance, including clinical audits, are common and expected in every clinical service organization. There are three tools that can be used to assist health care organizations to achieve these results, namely clinical standards, clinical indicators, and clinical audits. This has been realized by the hospital by having a list of clinical indicators that are used to measure clinical performance. The stage that still needs to be done by the hospital is to evaluate the results of the clinical performance measurement. There needs to be cooperation from all parties in the hospital, including the medical, nursing, and marketing committees. If the clinical performance measurement shows good results, then this can be used as a tool for hospital marketing, namely by showing the community that the hospital is able to provide good clinical services as shown by evidence of clinical performance measurement. The expected outcome is:

- Development of clinical pathways in clinical practice;

- Increased adherence to evidence-based clinical practice and reduced variation in clinical practice;

- Improved customer / patient outcomes Reduced health care costs through reduced side effects.

3. Clinical risk management All activities in the hospital have risks, both for the patient and for the officers in the hospital. However, it is necessary to ensure that the risks that arise are minimal. This third pillar focuses on minimizing clinical risks and increasing safety for patients and staff as a whole. This is achieved by identifying, reducing iris risks, and reducing unwanted events. The aspects covered by clinical risk management are: a) reporting, monitoring, and trend analysis of undesirable events, b) reporting, monitoring and clinical investigation of rare events (sentinel event), c) risk analysis, including identification, investigation, evaluation and clinical risk analysis. As a note, the patient safety committee or subcommittee is not the only party that plays a role in implementing this pillar, but is the responsibility of all staff and all parties in the hospital. Expected outcome:

- Improved monitoring and reporting of unexpected events;

- Improved monitoring of clinical incidents and unexpected incidents;

- Increasing the risk management process;

- Reduction of the number of unexpected occurrences.

4. Professional development and management this fourth pillar supports the clinical staff 
selection and recruitment process. In this case, professionalism continues to be developed, maintained, monitored and controlled. This process ensures that the appointed and hired staff is skilled and aware of new procedures. What is covered in this fourth pillar is competency standards and continuous professional development. The hospital makes efforts so that all staff can improve their competence, both on a joint scale and on a small scale. On a large scale, for example, by undergoing formal education, attending trainings. Meanwhile, competency improvement on a small scale is exemplified by learning through everyday experiences that appear and are discussed in morning meeting activities, where existing problems are solved by the hospital together and efforts are made for follow-up activities. Included in professional development and management is the management of staff performance. Hospitals already have Key Performance Indicators (KPI), even the existing KPIs have reached the individual level. It is also necessary to develop a KPI for doctors, a KPI for nurses, and a KPI for professionals. The Human Resources department is not the only part that is responsible for professional development and management at the hospital, but is the responsibility of all staff in the hospital, and the job of the internal auditor team is to ensure that all staff is involved in it. The expected outcomes were: Increased doctor credentials; Enhancing professional development and skills training for employees; Management performance improvement; and increasing employee job satisfaction.

Clinical Governance Standards are also developed consisting of 8 (eight) standards, which can be used in the clinical governance monitoring process, namely: Accountability; Policies and strategies; Organizational structure; Resource; Communication; Staff development and training; Performance measurement; and External Assessments.

Accountability The organization's responsibilities for clinical governance are clearly defined and there are clear job descriptions for each individual and field / unit, including the board of directors, management, medic committee and nursing committee and all clinical staff. The hospital must be able to show that:

- The Board of Directors has a description of the responsibilities for the four pillars of Clinical Governance;

- There is a special officer assigned to implement and manage the Clinical Governance program in the hospital;

- There are clear job descriptions for all organizations for Clinical Governance. In implementing the Clinical Governance program, it is the duty of all staff in the hospital (for example, the infrastructure, logistics, finance, etc. have their respective duties in implementing it), staff in each division know their respective duties to support the pillars. -Clinical Governance pillars;

- Clinical staff is involved in implementing the Clinical Governance program.

Organizational Structure Clinical Governance policies and strategies have been integrated with hospital organization. There is a clear division of tasks and those who are responsible for these tasks. The hospital must be able to show that: -There is a committee that is responsible for all aspects of Clinical Governance; -The committee has a clear description of duties and responsibilities related to activities for Clinical Governance; -The committee is responsible for coordinating and providing recommendations for all activities to Clinical Governance in all hospital coverage; - The committee members consist mainly of clinical staff active in clinical practice including at least one medical staff; - The committee reports to the director.

Resources the hospital provides human resources and other resources to support the implementation of Clinical Governance activities. The hospital must be able to show that:

- Human resources and other resources are provided as needed to support and implement Clinical Governance activities;

- Information technology is used as needed to support policies and strategies in Clinical Governance and to facilitate the dissemination of information to all parts of the hospital. The internal auditor team assesses whether the content and use of the intranet has been effective and supports the application of Clinical Governance. 
As an initial stage, the auditor team asks these questions specifically in certain units, if they have been trained, they can later ask other units in the hospital.

Hospital Communication communicates Clinical Governance policies and strategies to all staff and also to the public / patients and other hospital stakeholders. The organization must be able to demonstrate that: -Clinical Governance policies and strategies have been communicated properly to all staff and also to the public / patients and other hospital stakeholders (for example through the internet, posters, leaflets / brochures); - Hospital staff can understand and carry out their obligations as stated in the policies in Clinical Governance; -Policy documents in Clinical Governance in hospital reports (for example, hospital annual reports); Efforts to obtain feedback from patients on the quality of clinical services (both needs, expectations, and satisfaction). It is necessary to conduct a survey of patients (telephone, questionnaire, web interaction, etc.) regarding certain services (carried out by the person in charge of the unit, while the survey is generally carried out by the public relations department) and made periodic reports. The internal auditorium team asked all units about any efforts to obtain this feedback. The internal auditor team must know the hospital's annual report, even if one of the things that is assessed is whether or not there is an effort to implement Clinical Governance. The content of the year report is not only about the activity report but also contains the results and evaluation reports. Because not all of the contents of the hospital's annual report can be known by staff, the annual report is made briefly or in the form of a general report.

\section{METHODS OF RESEARCH}

Based on the thinking process framework model that shows the support of theoretical studies and empirical studies that produce hypotheses. And first it is necessary to form a framework model.

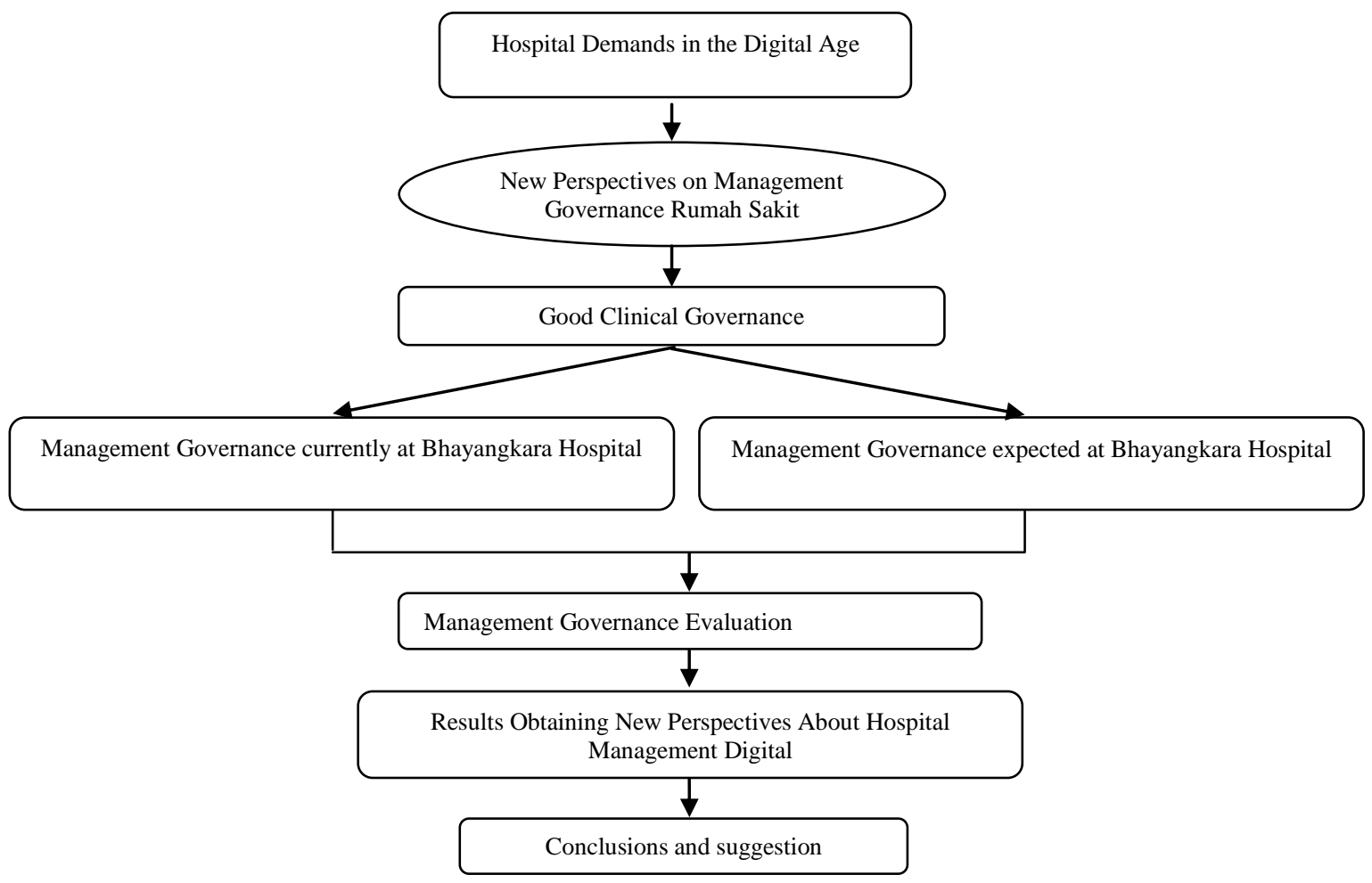

Figure 2 - Framework of Study

Determining the location of the research, Moleong (2010) determines the best way to be pursued by considering substantive theory and exploring the field and looking for conformity with the existing realities in the field. Meanwhile, geographic and practical limitations such as time, cost, and manpower need to be taken into consideration in 
determining the research location. The location taken in this study was determined purposively at Bhayangkara H. S. Samsoeri Mertojoso Hospital Surabaya.

Determining the focus of research is more directed at the level of newness of information to be obtained from the economic and social situation, this is intended to limit qualitative studies as well as limit research in order to choose which data is relevant and data that is not relevant (Moleong, 2010: 127). Limitation in qualitative research is based more on the level of importance and urgency of the problem to be solved. This research is focused on, among others, the pillars of Clinical Governance:

- Focus on the customer (customer value);

- Clinical performance and evaluation;

- Clinical risk management;

- Professional development and management;

- Has the finance department made a budget for education and training activities for employees?

- Has the public relations department made a survey for employee satisfaction at work?

\section{RESULTS AND DISCUSSION}

Bhayangkara H. S. Hospital Samsoeri Mertojoso is the UPT Pusdokkes Polri which is located under the Kapusdokkes Polri as the supervisor of the technical functions of police medicine and police health, for operational and administrative technical implementation is responsible to the Head of Regional Units and the Head of the corresponding organizational unit Bhayangkara HS Hospital Samsoeri Mertojoso as one of the health facilities that provide Health services have a very important role in improving public health, implementing comprehensive health services and having sophisticated and high-quality human resources, professional and moral. Bhayangkara H.Samsoeri Mertojoso Hospital organizes Police Medical Services and Procedural Police Health in improving the quality and patient safety for members of the National Police, PNS Polri, their families and the general public.

Personnel Strength. There are 558 employees / personnel who work at Bhayangkara H.S.Samsoeri Mertojoso Hospital, consisting of members of the Police, PNS Polri, contract workers and partner staff. If detailed based on the class and educational qualifications are as follows: In accordance with the type of hospital type B, the need for doctors and specialists and subspecialists must be met at the Bhayangkara H.S Samsoeri Mertojoso Hospital. General practitioners, general dentists, specialist doctors, specialist dentists, and subspecialist doctors or consultants for organic bias, namely members of the Police and PNS Polri, and bias from partner doctors. For other health workers, namely nurses, midwives, laboratory workers, radiology officers, pharmacies, apart from organic, they are also BLU contract workers. In addition to medical personnel, paramedics also include non-medical personnel, namely employees of IPPRS, Loundry, IPAL, and employees in management such as admissions, finance, binfung, materials and logistics as well as security. Acceptance of partners and contracts, both medical and non-medical, through a credential process according to their respective fields and expertise.

Online Patient Registration. Bhayangkara H.S Samsoeri Mertojoso Hospital Surabaya provides online patient registration services but only for old patients who already have a RM (Medical Record) number. Registration is done before the day the patient goes for treatment, for example: for registration on Monday the patient is required to register online on Sundays at 00:00 - 20:00 WIB. Registration is declared valid if you have received a reply / confirmation in the form of a register number. When the patient arrives, collect the files to the verification officer at counter 1 , and then they will be called according to the queue number.

Hospital Management Information System. Management Information Systems are data processing procedures based on information technology and are integrated with manual procedures and other procedures to produce timely and effective information to support the management decision-making process. In the health sector, especially hospitals really need a Management Information System to improve the quality of services for the community to 
welcome "Healthy Indonesia 2010". The role of SIMRS (Hospital Management Information System), namely:

- Hospital Management Information System (SIMRS) is needed so that the hospital can improve its services to both the general public and the management;

- With the SIMRS, the business processes in the hospital can be timely and effective, especially in the decision-making process;

- The class and status of the hospital will influence the need for selecting the information system to be used.

E-Prescription Pharmacy Installation. E-Prescription is intended to help doctors to increase efficiency and limit medical errors. This electronic prescription avoids the possibility that a patient could get the wrong medication because the doctor was careless in writing it down. By using e-prescription, a doctor only needs to write on a device, then send it to the pharmacist. The use of this e-prescription will reduce the error rate in reading prescriptions written by doctors. However, this still poses a big risk if there are parties who try to extract the contents of the recipe and then exchange the contents or there are several parties who try to fake the identity in it (a case of falsifying the recipe). The application or implementation of electronic prescriptions that are added with a digital signature application can increase the safety of prescriptions sent by doctors to pharmacists. The use of digital signatures can also avoid criminal acts such as: forgery of prescriptions for certain purposes and malpractice operations performed by doctors (by obtaining anti-denial facts). The interface is designed for both doctors and pharmacists who are connected to the internet by prioritizing the userfriend aspect so that the use of e-prescriptions added by the digital signature application can be used easily.

Completeness of Input Documents. Almost all informants stated that they had various versions of the organizational culture policy, although not all of them contained a direct relationship with the hospital. Not all informants have been able to show written documents related to hospital culture, such as Director's Decree (SK) and SOP. Not all informants have written documents in the form of policies, Director's Decrees, and SOPs on financial information management, such as when to regularly discuss financial performance accountability internally in the hospital.

Completeness of Process Documents. Hospital policies, starting from the decree on institutional determination, including the organizational structure, management officers, staff, and organizational structures, have been owned by the hospital. Renstra documents, Business Budget Plans, Hospital by Laws that have been approved by the Supervisory Board are available throughout the Hospital. Policies regarding hospital performance reports as well as the guidance and supervisory process are also on the side of the hospital. The policy for the distribution of incentives in each new hospital, based on internal policies, has not been endorsed by the National Police Headquarters.

Completeness of Output Documents. Of all the output documents that were questioned, only remuneration documents were not owned by the hospital. All Hospitals have carried out the process of compiling and submitting to the Hospital Directors, but the Hospital Directors have not submitted a submission to the National Police Headquarters, so no remuneration SK has been passed yet. Another policy related to hospitals is the hospital rate document that has been submitted by the hospital to the hospital board of directors.

Factors Influencing Management of Bhayangkara Hospital Surabaya. From the results of interviews about the input, process, and output variables, there are 12 factors that influence the governance of Bhayangkara Hospital Surabaya:

- Culture. A public service culture is an independent culture, especially related to integrity and discipline in changing planning, service systems and remuneration to always develop its business as much as possible in order to provide the best ability to customers. Cultural change can occur when an institution, from the leadership to the entire staff, is committed to carrying out an agreed culture. Bhayangkara H.S Samsoeri Mertojoso Hospital Surabaya has launched a cultural change which is expected to be implemented by all staff, Bhayangkara H.S. Hospital. Samsoeri 
Mertojoso Surabaya has a clear and comprehensive program on corporate culture which is disseminated to all staff.

- The appointment of Bhayangkara H.S. Samsoeri Mertojoso Surabaya. Currently, it has obtained the status of public services based on the Satker PK-BLU Kep Menkeu No. 429 / KMK.05 / 2010 on November 3, 2010 concerning the Establishment of a Public Service Agency. This determination is a very important institutional basis that needs to be discussed and evaluated regularly at the Ministry of Health and Police Headquarters levels. The essence of public services as a public service provider that has been given flexibility must be properly understood by the administrators and the technical ministries. The Ministry of Finance stated that it would give a warning to the public service Satker who were deemed unsuccessful in achieving the agreed objectives. Hospital Directors must understand the concept of public services, but do not let the Corruption Eradication Commission (KPK) find findings due to mismanagement. According to what is stated in Government Regulation No. 23 of 2010 Chapter III concerning Requirements, Determination and Revocation, The second part of article 6 states that the status of public services can be revoked if the person concerned is deemed unable to meet the substantive, technical and administrative requirements.

- Hospital by Laws. The shift in the hospital paradigm from a social institution to a socio-economic institution that can be used as a legal subject, this needs to be anticipated by the clarity of the rights and responsibilities of each party with an interest in hospital management, which will be regulated in Hospital by laws (Statute). ) (Erikson, 2014). Hospital as a high health service institution. It does not rule out the possibility of conflict between interested parties, both between the customer and the service provider, as well as between the owner and the manager or manager. Hospital by Laws (HBL) on the hospital side has been compiled and implemented in accordance with the Decree of the Minister of Health of the Republic of Indonesia No. 772 / Menkes / SK / VI / 2012. The approval is carried out by the Hospital Directors with the recognition of the Hospital Supervisory Board representing the owner (Governing Bodies). Understanding the contents of Hospital by Laws needs special attention considering that the household budget at each Bhayangkara Hospital in Surabaya requires firmness and also understanding of the entire ranks. Based on the Decree of the Indonesian Minister of Health no. 772 / Menkes / SK / VI / 2012 concerning Hospital Internal Regulations (Hospital by Laws), Hospital by Laws was prepared with the aim of regulating the relationship between the Board of Directors and the Supervisory Board (Dewas) of Medical Staff, in accordance with the Decree of the Minister of Health of the Republic of Indonesia No .: 772 / MENKES / SK / VI / 2012 concerning Hospital Internal Regulations (Hospital by Laws). HBL needs to be raised at Bhayangkara Hospital Surabaya so that the suitability of the performance and main duties and functions between the owner or governing body and the manager, in this case the Directors of the Bhayangkara Hospital Surabaya, can be assessed periodically and transparently. In fact, the HBL in the hospital has not been totally implemented and used as a guideline in the management of public services.

- Strategic Plan (Renstra) and RBA. In general, the mechanism for submitting the Strategic Plan and RBA is carried out by the hospital with the approval of the Board of Directors of the Hospital and Public Service Police Headquarters to prepare an annual RBA with reference to the five-year business plan. The RBA is compiled on the basis of performance and calculation of costs according to the type of service as well as based on the needs and ability of the income that is expected to be received from the community, other agencies. The RBA submitted to the National Police Headquarters is accompanied by a proposed minimum service standard and the cost of the output to be produced, to be submitted to the National Police Headquarters so that it can be reviewed in accordance with public service standards and mutually agreed. Renstra and RBA can be improved if there are urgent principles on the way. Renstra and RBA changes must be approved by the Supervisory Board. 
- Management information System. The anatomy of the hospital is so large and complex that it will be very difficult to rely on manual arrangement and management, so tools are needed to be able to manage and organize quickly, precisely and accurately so that excellence services can be produced, this tool is an Information Technology solution packaged in Integrated SIMRS software products that are specially designed based on Client Server that manage all manual processes from $A$ - Z to be processed and converted electronically and in real time from handling registration / medical records, outpatient care, billing, pharmacy, inventory, finance, inpatient, supporting installation etc.

- Procurement of goods and services. Basically, public services can be partially or completely exempted from the generally accepted provisions for the procurement of government goods and services, if there are reasons for effectiveness and / or efficiency. The system for procuring goods and services at public service hospitals should be more flexible. But in reality, almost all informants stated that they were difficult to procure goods and services, the amount of which was still limited to below 200 million rupiah for direct appointment, needed to be discussed further with the technical ministry, in this case the National Police Headquarters, in order to increase the amount and document it in regulations legal one.

- Establishment of Service Standards. Documents that must be presented by public service government agencies are Minimum Service Standards which must pay attention to service quality, equality and equality of services, costs and ease of access to services. There must be a balance between the public sector and the private sector in the field of health services, the current government needs to strengthen the government sector. This strategy should exist at a higher level and will be used as a guideline at the ministerial level. In hospitals that can achieve international service standards, they should receive support in the fulfillment of facilities and facilities.

- Determination of Service Rates. In principle, tariffs must be able to maintain the existence of hospitals, including through efforts to develop class I and VIP services by taking into account people's purchasing power, must be fair and proper, and must pay attention to competitors' rates. However, in fact, until now the National Police Headquarters has not received the proposed tariff for Bhayangkara Hospital in Surabaya from the Police Headquarters.

- Managing Officer. There is already a guideline regarding the management officers of the Bhayangkara Hospital in Surabaya and the managing officers are financial officials, such as KPA, PPK, and Procurement Service Units, but in fact it is necessary to consider the presence of technical officials who also need to be professional. Public service technical officers are tasked with planning technical activities in their respective fields, carrying out technical activities in accordance with the RBA and being accountable for operational performance in their respective fields. It seems that the emphasis that there is a close relationship between technical officials and financial managers regarding the RBA needs to be greatly enhanced.

- Remuneration. Managing officers, Dewas, and public service employees can be given remuneration based on the level of responsibility and the required professionalism. Yusuf (2017), Remuneration is indeed one of the steps in accelerating reform and bureaucracy, including one of which is to improve performance and work ethic to achieve optimal service performance. Remuneration must be implemented and each performance output needs to be pursued. Salaries and allowances must be integrated into the calculation of take home pay at each satker.

- Staffing. Because public service management officers can consist of civil servants and / or professional non-civil servants according to the needs of public services, each public service is required to calculate in detail or analyze the amount of manpower required according to the workload. The appointment of non-civil servant 
human resources for public services does not require the approval of the Ministry of Panic, but the most important thing is that it is in accordance with the ability of the public service Satker, especially the issue of personnel costs. The only human resources that are required are the Head of the Satker who is the Proxy of Budget Users. The rights and obligations of non-civil servant human resources in public services should be equal to those of public service civil servants.

- Development and Supervision. Internal inspection of public services is carried out by the Internal Audit Unit (SPI), which is a work unit that is directly under the leadership of public services. External inspection of public services is carried out by external inspection in accordance with statutory regulations, usually an assessment is requested from a public accountant, apart from the Supreme Audit Agency (BPK) or the Inspectorate General of Hospital Directors. SPI and Dewas should move from planning. SPI is an internal controller stated in the State Treasury Law, while Dewas has the authority to represent the interests of the Ministry so that public services can run properly. Public service Dewas within the central government was formed by the decision of the Head of the institution with the approval of the National Police Headquarters with the main task of Dewas signing the RBA, supervising the write-off of accounts, including paying attention to the performance of public services.

\section{CONCLUSION AND SUGGESTIONS}

Based on observations and research results aimed at evaluating New Perspectives on Management Management Analysis in Facing the Digital Era at Bhayangkara H.Samsoeri Mertojoso Hospital Surabaya, the author can make a conclusion that:

- The implementation of Good Corporate Governance at the Hospital of Bhayangkara H.S.Samsoeri Mertojoso Surabaya has been carried out optimally. In carrying out its duties Karumkit has directed staff well at work and has provided training, both from internal and external to the Hospital. Karumkit, heads of fields and units have made time to hold regular meetings, carry out their duties and obligations according to their respective main tasks and descriptions. In determining the organizational structure, qualifications from Karumkit, head of fields, unit heads and clinical and non-clinical staff have been carried out properly with the existence of a decision letter of appointment, job descriptions, authority, for clinical staff credentials have been carried out, both doctors, nurses / midwives, and professional givers. Other care (PPA) such as Medical Records, Pharmacists, Assistants, Physiotherapy, Chemical Analysts, Public Health. Employees at work are always responsible for carrying out the hospital's mission to provide better service to patients;

- Policies, Standard Operating Procedures (SPO), for each standard have been made by the Accreditation Team which has been approved by Karumkit, but due to the limited staff working on them, the implementation of Good Corporate Governance through Accreditation of Hospital Management cannot run optimally. Reporting from superior programs in patient care, management has done well and training has been carried out for personnel or staff who will monitor and evaluate the implementation of superior programs in these services. To measure the success of a hospital activity, it is necessary to involve all staff to maintain and maintain it.

Based on the results, discussion, and conclusions from the research results, the authors suggest:

- Limited staff willing to work due to the workload received, the authors suggest that two or three people be appointed in one Accreditation Team to work fully to help and do the work of the Accreditation working group in carrying out activities in accordance with the standards of the instruments that have been set together;

- In the future, in accepting employees, it must be adjusted to their competencies, so that the staff can work more effectively;

- For further researchers, it is hoped that they can examine more deeply in other working groups regarding research related to Good Corporate Governance so that 
the research results become one of the information that can be used by the hospital and for further research.

\section{REFERENCES}

1. Kasyfi Hartati, Hanevi Djasri, Adi Utarini.(2014). Implementasi TataKelola Klinis Oleh Komite Medik Di Rumah Sakit Umum Daerah Di Provinsi Jawa Tengah. Pusat Manajemen dan Pelayanan Kesehatan, Universitas Gajah Mada, Yogyakarta. Bagian IImu Kesehatan Masyarakat, FKUGM, Yogyakarta.

2. Widajat, Rochmanadji. (2009). Being a Great and Sustainable Hospital. Jakarta: Gramedia Pustaka Utama.

3. Utarini A. Mutu Pelayanan Kesehatan dilndonesia: Sistem Regulasi yang Responsif. Pidato Pengukuhan Jabatan Guru Besar pada Fakultas Kedokteran Universiatas Gadjah Mada.Yogyakarta. 2011. 13. KARS. Standar Akreditasi Rumah Sakit.Jakarta.2011.

4. DjasriH. Penerapan Clinical Governance Melalui ISO 9000: Studi Kasus di Dua Rumah Saskit Unit Darurat (RSUD) Provinsi Jawa Timur. Jurnal Manajemen Pelayanan Kesehatan. 2006; 09(03):121-8.

5. Pridmore JA. A comparative review of clinical governance arrangement sintiie UK.Independent Review.2007; 16(12):720-4.

6. Menteri Kesehatan. PerMenkes Republik Indonesia No 755 /Menkes /PER/IV/2011 tentang Penyelenggaraan Komite Medik diRumah Sakit. 2011; 1-46.

7. Nugroho, Riant. (2012). Public Policy: Dinamika Kebijakan, Analisis Kebijakan, Manajemen Kebijakan. Jakarta: Kompas Gramedia.

8. Yusup Nur.2017. Analisis Pengaruh Implementasi Good Corporate Governance (GCG) Pada Remunerasi Terhadap Kinerja Karyawan Rumah Sakit UNS Surakarta. Universitas Muhammadiyah Surakarta.

9. Syahril Rizal, Rasmila. (2015), TataKelola Teknologi Informasi Rumah Sakit Kusta Dokter Rivai Abdullah Palembang. Universitas Bina Darma.

10. Erikkson Sitohang. Prinsip Hukum Dalam TataKelola RumahSakit. Fakultas Hukum Universitas Mahendradatta. Yuridika: Volume 29 No1, Januari-April 2014. 